\title{
Comparison of Carcinoembryonic Antigen Serum Levels in Colorectal Cancer Patients with Different Histopathological Grades
}

\author{
Chandra Agusrly, ${ }^{1}$ Taufik Sungkar, ${ }^{2}$ Gontar Alamsyah Siregar ${ }^{2}$ \\ ${ }^{1}$ Faculty of Medicine Universitas Sumatera Utara, Medan, Indonesia, ${ }^{2}$ Gastroenterology and Hepathology \\ Division, Departement of Internal Medicine Faculty of Medicine Universitas Sumatera Utara/ \\ H. Adam Malik General Hospital Medan, Indonesia
}

\begin{abstract}
Histopathological grading, which represents the degree of histopathological differentiation, is often used as one of the factors to determine the prognosis of colorectal cancer. However, this grading cannot comprehensively present the clinical features of the disease. Carcinoembryonic antigen (CEA), as a tumor marker tested in the laboratory, is commonly used to determine the diagnosis and prognosis of colorectal cancer. The purpose of this study was to determine differences in CEA serum levels based on the cellular differentiation of colorectal cancer. This was a cross-sectional analytical study on medical records of colorectal cancer patients who were admitted to H. Adam Malik General Hospital Medan, Indonesia from January 2016 to December 2018. As many as 52 medical records of colorectal cancer patients who met the inclusion and exclusion criteria were included in this study. These patients were then divided into three groups based on the histopathological grade: well-differentiated, moderately differentiated, and poorly-differentiated. The Kruskal-Wallis test was then used to compare the CEA levels in these different histopathological grades. Results show that the CEA serum level was different in colorectal cancer patients with different histopathological grades $(p=0.020)$. The CEA level was significantly higher in the poorly-differentiated group than the well-differentiated $(p=0.044)$ and moderately differentiated $(p=0.015)$ groups. Hence, the CEA level of colorectal cancer patients with poorly-differentiated grade is the highest when compared to other grades.
\end{abstract}

Key words: Colorectal cancer, carcinoembryonic antigen, histopathological grade

\section{Perbandingan Kadar Serum Carcinoembryonic Antigen berdasar atas Derajat Histopatologi Pada Pasien Kanker Kolorektal}

\begin{abstract}
Abstrak
Derajat diferensiasi dapat dijadikan sebagai salah satu faktor prognosis pada kanker kolorektal. Namun, penilaian ini tidak dapat menyajikan gambaran klinis penyakit secara komprehensif. Penanda tumor carcinoembryonic antigen (CEA) sebagai penanda tumor yang diuji di laboratorium, umumnya digunakan untuk menentukan diagnosis dan prognosis kanker kolorektal. Tujuan dari penelitian ini adalah menentukan perbedaan kadar serum CEA berdasar atas diferensiasi sel kanker kolorektal. Penelitian ini merupakan penelitian analitik dengan desain potong lintang dengan menggunakan data rekam medis pasien yang didiagnosis kanker kolorektal di Rumah Sakit Umum Pusat H. Adam Malik, Medan periode Januari 2016 hingga Desember 2018. Sebanyak 52 catatan medis pasien kanker kolorektal yang memenuhi inklusi dan kriteria eksklusi pada penelitian ini. Derajat diferensiasi dikelompokkan menjadi tiga: derajat baik, sedang, dan buruk. Uji Kruskal-Wallis digunakan untuk membandingkan kadar CEA berdasar atas derajat diferensiasi. Hasil menunjukkan bahwa kadar serum CEA berbeda pada pasien kanker kolorektal dengan nilai histopatologis yang berbeda $(p=0,020)$. Tingkat CEA secara signifikan lebih tinggi pada kelompok berdiferensiasi buruk daripada kelompok berdiferensiasi baik $(p=0,044)$ dan kelompok berdiferensiasi sedang $(\mathrm{p}=0,015)$. Oleh karena itu, tingkat CEA pasien kanker kolorektal dengan derajat diferensiasi buruk adalah yang tertinggi jika dibanding dengan tingkat lainnya.
\end{abstract}

Kata kunci: Carcinoembryonic antigen, derajat diferensiasi histopatologi, kanker kolorektal

Corresponding Author: Chandra Agusrly, Faculty of Medicine Universitas Sumatera Utara, Medan, Jalan Dr. T. Mansur No. 5 , Medan 20115, North Sumatera, Indonesia, Email: chandra.agusrly@gmail.com 


\section{Introduction}

Colorectal cancer is a cancer that occurs in the colon or rectum. ${ }^{1}$ It shows progressively increasing cases and mortality in the general population. $^{2}$ In general, the development of colorectal cancer is an interaction between environmental and genetic factors, which can be modifiable or non-modifiable. The nonmodifiable factors include family history of colorectal cancer or polyp adenoma and individual history of chronic inflammatory bowel disease while the modifiable risk factors include sedentary lifestyle, obesity, high consumption of red meat, smoking, and moderate to heavy alcohol consumption. In addition, fiber and vitamin D intake are included as the protective factors. $^{3}$

Early detection of early-stage lesions can reduce the morbidity and mortality of colorectal cancer malignancy. Colonoscopy is still considered as a significant tool for early detection. On the other hand, grading is one of the systems used to determine the prognosis of colorectal adenocarcinoma. However, it does not fully predict patient output, making the use of prognostic markers necessary. ${ }^{4,5}$ To assist with the diagnosis, monitoring of non-invasive markers is needed to detect early colorectal cancer.

Carcinoembryonic antigen (CEA) serum is the most commonly used biomarker in laboratory tests for screening, diagnosis, prognostication, and monitoring of treatment and recurrence in patients with colorectal cancer. ${ }^{5}$ Seventy-two point four percent $(72.4 \%)$ of colorectal cancer patients have elevated levels of CEA. ${ }^{4}$ This study aimed to determine differences in CEA serum levels based on colorectal cancer cellular differentiations.

\section{Methods}

This study is a cross-sectional analytical study design conducted in H. Adam Malik General Hospital, Medan, Indonesia, from July 2019 to November 2019 on 71 patients diagnosed with colorectal cancer by doctors during the period of January 2016-December 2018. The inclusion criteria were patients diagnosed with colorectal cancer based on colonoscopy and histopathological examinations with well, moderately, and poorly differentiated adenocarcinoma. The exclusion criteria were incomplete medical record data and patients suffering from other comorbid diseases such as hepatitis and hyperthyroidism. The following data were collected from the medical records: gender, age, CEA level, tumor location, and grading. The study protocol was approved by the Health Research Ethical Committee of Faculty of Medicine, Universitas Sumatera Utara under the reference number of 02/ TGL/ KEPK FK USURSUP HAM/2019.

Statistical analysis was performed using SPSS version 22.0 with the level of significance set at $\mathrm{p}<0.05$. To compare carcinoembryonic antigen serum levels by histopathological grade, Kruskal-Wallis test was used, followed by the Mann-Whitney test to determine the difference between carcinoembryonic antigen serum levels in various grading groups.

\section{Results}

In total, 52 medical records of colorectal cancer patients were included in this study. The characteristics of these patients, i.e. gender, age, site of cancer, grading, and CEA level, are presented in Table 1. The statistical analysis was conducted to determine differences in the CEA levels based on the histopathological grading using the Kruskal-Wallis test with a confidence interval of $95 \%$.

Table 2 presents the Kruskal-Wallis test results, showing that a significant difference ( $p=0.020$ ) was observed between grading and carcinoembryonic antigen serum level. The post hoc test was then used to determine which group shows a difference. Well and poorly differentiated groups, and moderately and poorly differentiated groups showed a significant difference with $\mathrm{p}=0.044$ and 0.015 , respectively. Meanwhile, the well and moderately differentiated did not show a statistically significant difference $(p=0.114)$ (Table 3).

\section{Discussion}

Carcinoembryonic antigen (CEA), an oncofetal glycoprotein, is expressed in normal mucosal cells and overexpressed in adenocarcinoma, especially in colorectal cancer. ${ }^{6}$

In this study, patients with colorectal cancer were dominated by $63.5 \%$ of $\geq 50$-years-old patients followed by $36.5 \%$ of $<50$-years-old patients. The colorectal cancer risk increases with age, with more than $90 \%$ occurs at the age of over 50 years old; however, it can strike at any 
Table 1 Subject characteristics $(n=52)$

\begin{tabular}{lc}
\hline \multicolumn{1}{c}{ Variable } & $\mathbf{n}(\%)$ \\
\hline Age (years) & $33(63.5 \%)$ \\
$<50$ & $19(36.5 \%)$ \\
Mean \pm SD & $53 \pm 13.69$ \\
Gender & \\
$\quad$ Male & $28(53.8 \%)$ \\
$\quad$ Female & $24(46.2 \%)$ \\
Site of cancer & \\
Right-sided & $5(9.6 \%)$ \\
Left-sided & $21(40.4 \%)$ \\
Rectum & $26(50 \%)$ \\
Grading & \\
Well differentiated & $21(40.4 \%)$ \\
Moderately differentiated & $22(42.3 \%)$ \\
Poorly differentiated & $9(17.3 \%)$ \\
CEA (ng/mL) & $6.4(0.98-1968.95)$ \\
\hline
\end{tabular}

*Values are median (minimum-maximum) decade. $^{7}$ This is because in elderly, the ability of cells and tissues to repair and maintain the normal structure when there are cell damages is reduced. Therefore, the body's immune system gradually decreases, leading to various metabolic distortions that may trigger degenerative and age-related diseases such as colorectal cancer. ${ }^{8,9}$

Some literature stated that the male gender has a slightly higher risk for colorectal cancer than females. Male gender was indeed predominant in this study, which is similar to the finding of a study by Rahdi et al., ${ }^{7}$ stating that colorectal cancer cases were found in 22 men (56.41\%) and 17 women (43.59\%). However, this is different from the finding of a study conducted in Immanuel Hospital, Bandung, Indonesia that observed that more women suffer from colorectal cancer (57.1\%) than men $(42.9 \%) .{ }^{10}$ Another study observed a two-fold increased risk of colorectal cancer and advanced adenomas in men compared to women, showing that men are more at risk for colorectal cancer. ${ }^{11}$ It is suspected that this is due to the tendency of men to prefer diets that are high in red meat and its processed products as well as a higher alcohol consumption and smoking habit and a greater chance of visceral fat accumulation associated with an increased risk of colorectal cancer. ${ }^{12}$

Frequency distribution based on the location

Table 2 Comparison of CEA Serum Levels Based on Histopathological Grade

\begin{tabular}{|c|c|c|c|c|}
\hline \multirow[b]{2}{*}{ Variable } & \multicolumn{3}{|c|}{ Total $(n=52)$} & \multirow[b]{2}{*}{$\mathbf{p}^{* *}$} \\
\hline & $\begin{array}{l}\text { Well Differentiated } \\
\qquad(\mathrm{n}=\mathbf{2 1})\end{array}$ & $\begin{array}{c}\text { Moderately } \\
\text { Differentiated } \\
(n=22)\end{array}$ & $\begin{array}{l}\text { Poorly Differentiated } \\
\qquad(n=9)\end{array}$ & \\
\hline \multirow{4}{*}{ CEA serum level } & & $*$ & \multirow{4}{*}{ 216.31(1.81-1968.95) } & \multirow{4}{*}{0.020} \\
\hline & & $6.64(1.07-218.55)$ & & \\
\hline & & .35 & & \\
\hline & & $4.74(0.98-1759)$ & & \\
\hline
\end{tabular}

* Values are median (minimum-maximum); ** Kruskal-Wallis Test

Table 3 Comparison of CEA Serum Levels between Grading Groups

\begin{tabular}{lcc}
\hline \multicolumn{1}{c}{ Grading Group } & CEA Serum $(\mathbf{n g} / \mathbf{m L})^{*}$ & $\mathbf{p}^{* *}$ \\
\hline Well- vs moderately-differentiated & 664 vs 4,74 & 0,114 \\
Well- vs poorly differentiated & 6.64 vs 216 & 0.044 \\
& .31 & \\
Moderately - vs poorly differentiated & 4.74 vs 216 & 0.015 \\
\hline
\end{tabular}

* Values are median; **Mann-Whitney test 
of cancer of colorectal cancer patients showed the majority of cancer is located in the rectum $(n=26,60 \%)$, followed by the left colon and right colon. The results of this study are similar to the finding of a study by Su et $a . .^{13}$ that the most common site of colorectal cancer is rectum (57.9\%). Yusra et al. ${ }^{10}$ also obtained a similar result showing that the most common location of colorectal cancer was rectum (55.9\%). This is in contrast with the result of Gunasekaran et al. ${ }^{14}$ stating that the most frequent site of colorectal cancer is colon $(40.5 \%)$. The fact that the predominant site of the cancer is rectum may relate to the consumption of a low-fiber and high-fat diet, making the transit time of stool in the rectum to be longer. Therefore, the mucosal contact related to the process of inflammation and infection is longer. ${ }^{15}$

The Kruskal-Wallis test results showed that the CEA level increases with histopathological grading of colorectal cancer and the difference is statistically significant $(\mathrm{p}=0.020)$. That it can be concluded that there are differences in the CEA level based on the histopathological grade. This result is similar to a study by Wesley et al. ${ }^{16}$ $(\mathrm{p}<0.0001)$.

In the case of colorectal cancer, there are disruptions in the structure of normal tissue and neoplasm cells located in the tumor gland, causing the inability of the cells to polarize and express CEA on the cell surface. It affects the distribution of CEA in the blood vessels or lymph vessels through the intercellular space. As a result, it increases the CEA levels in colorectal cancer patients that show poor differentiation compared to other groups. ${ }^{17}$ However, several previous studies have shown that welldifferentiated colorectal cancer has higher CEA levels. $^{15}$

It is concluded that there is a difference in CEA levels based on the histopathological grade in colorectal cancer patients with $\mathrm{p}=0.020$. Poorly differentiated grade has a higher CEA serum level than in other gorups. The CEA serum levels tend to increase with increasing histopathological grade.

\section{References}

1. American Cancer Society. Colorectal cancer facts \& figures 2017-2019. Atlanta: American Cancer Society; 2017.

2. Effendi-YS R, Rey I. Cancer stem cells and signaling pathways in colorectal cancer. Indones J Gastroenterol Hepatol Dig Endosc.
2018;19(1):37-41.

3. Kemenkes RI. Panduan Penatalaksanaan Kanker Kolorektal. Jakarta: Kemenkes RI; 2015.

4. Wichendu PN, Amadi C. Relationship between plasma calcium and carcinoembryonic antigen among colorectal cancer patients. Int Sur J. 2018;5(6):1995-9.

5. Permana FR, Budiono BP, Farida $\mathrm{H}$. Hubungan kadar carcinoembryonic antigen (CEA) dan albumin serum dengan lokasi kanker kolorektal. JKD. 2016;5(4):808-16.

6. Jain S, Pincus MR, Bluth MH, Mcpherson RA, Bowne WB, Lee P. Diagnosis and management of cancer using serologic and other body fluid markers. In: Mcpherson RA, Pincus MR, editors. Henry's clinical diagnosis and management by laboratory methods. $23^{\text {rd }}$ ed. St. Louis, Missouri: Elsevier Inc.; 2019. p. 1432-49.

7. Rahdi DR, Wibowo AA, Rosida L. Gambaran faktor risiko pasien kanker kolorektal di rsud ulin banjarmasin periode April-September 2014. Berk Kedokt. 2015;11(2):221-32.

8. Bellantuono I, Potter PK. Modelling ageing and age-related disease. Drug Discov Today Dis Model. 2016;20(22):27-32.

9. Franceschi C, Garagnani P, Morsiani C, Maria C, Santoro A, Grignolio A, et al. The continuum of aging and age-related diseases: common mechanisms but different rates. Front Med. 2018;5(61):1-22.

10. Yusra CA, Virghiandy I, Novianry V. Gambaran pasien kanker kolorektal di rsud dr. Soedarso pontianak periode tahun 2006-2010. J Mhs Fak Kedokt UNTAN. 2013;2(1):1-25

11. Gandomani HS, Yousefi SM, Aghajani M, Mohammadian-Hafshejani A, Tarazoj AA, Pouyesh V, et al. Colorectal cancer in the world: incidence, mortality and risk factors. Biomed Res Ther. 2017;4(10):1656-75.

12. White A, Ironmonger L, Steele RJC, OrmistonSmith N, Crawford C, Seims A. A review of sex-related differences in colorectal cancer incidence, screening uptake, routes to diagnosis, cancer stage and survival in the UK. BMC Cancer. 2018;18(1):906.

13. Su B Bin, Shi H, Wan J. Role of serum carcinoembryonic antigen in the detection of colorectal cancer before and after surgical resection. World J Gastroenterol. 2012;18(17):2121-6.

14. Gunasekaran V, Ekawati NP, Sumadi IWJ. Karakteristik klinikopatologi karsinoma kolorektal di RSUP Sanglah , Bali , Indonesia tahun 2013-2017. Intisari Sains Medis. 
2019;10(3):552-6.

15. Sutrisna IWW, Sudartana IK, Widiana IGR. Hubungan antara gradasi histopatologis dan kadar carcinoembryonic antigen pada karsinoma kolon. Medicina. 2018;49(1):228.

16. Wesley J, Mambu T, Sapan H, Sumanti WM. Hubungan nilai carcinoembryonic antigen dengan derajat diferensiasi pada karsinoma kolorektal di RSUP Prof. Dr. R. D. Kandou Manado. JBM. 2018;10(2):92-6.

17. Huang SH, Tsai WS, You JF, Hung HY, Yeh CY, Hsieh PS, et al. Preoperative carcinoembryonic antigen as a poor prognostic factor in stage I-III colorectal cancer after curative-intent resection: A Propensity Score Matching Analysis. Ann Surg Oncol. 2019;26(6):1685-94. 